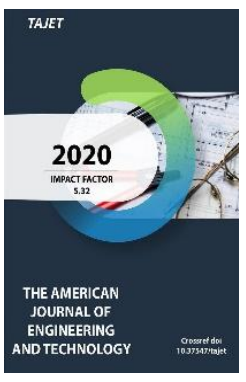

\title{
New Uzbekistan New World View - In The Eyes Of Architects
}

\author{
M.S.Zikirov \\ Lecturer, Department Of Architecture, Fergana Polytechnic Institute, Uzbekistan \\ B.R.Toshpo'latova \\ Master's Student, Department Of Architecture, Ferghana Polytechnic Institute, Uzbekistan
}

Journal Website:

http://usajournalshub.c

om/index,php/tajet

Copyright: Original content from this work may be used under the terms of the creative commons attributes

4.0 licence.

\section{ABSTRACT}

This article discusses the creative work carried out in our country in recent years, changes in urban development, the effectiveness of international cooperation in the field of construction and new buildings and structures being restored. The results of new technologies used in architecture and urban planning are explained.

\section{KEYWORDS}

Arena, transformation, exclusive, ice rink, architectural idea, VIP box, rental agent, alternative.

\section{INTRODUCTION}

It is no secret that the developments of our country, the efforts for the welfare of our people are raising to a new level. A clear example of this is the fact that people's lives are improving day by day, the joy on their faces, the confidence in the future is growing. Radical reforms in the life of our country show that the worldview of every citizen living on this land is changing, and the sense of involvement in the fate of the country is growing. An example of this is the modern buildings being built in our country. 


\section{MATERIALS AND METHODS}

Humo Arena is a large multifunctional sports and entertainment complex and the Ice Palace in Tashkent, the capital of Uzbekistan. It is located in the central part of the city, in the Chilanzar region, at the intersection of Afrasiyab and Beshyogach streets (Fig. 1). It is the largest ice complex in Central Asia and the second largest in the CIS after Belarus' Minsk Arena. It is the home arena of several hockey clubs in Tashkent: Humo, Binokor, Semurg and Tashkent.
- In July 2017, a project proposal was submitted.

- Built-in March 2019.

- Opened on March 15, 2019.

- Architect Institute of Unique Structure Design "LI Arena"

- Developer Wind Rose

- Capacity 12500 (main arena) 200 small arena

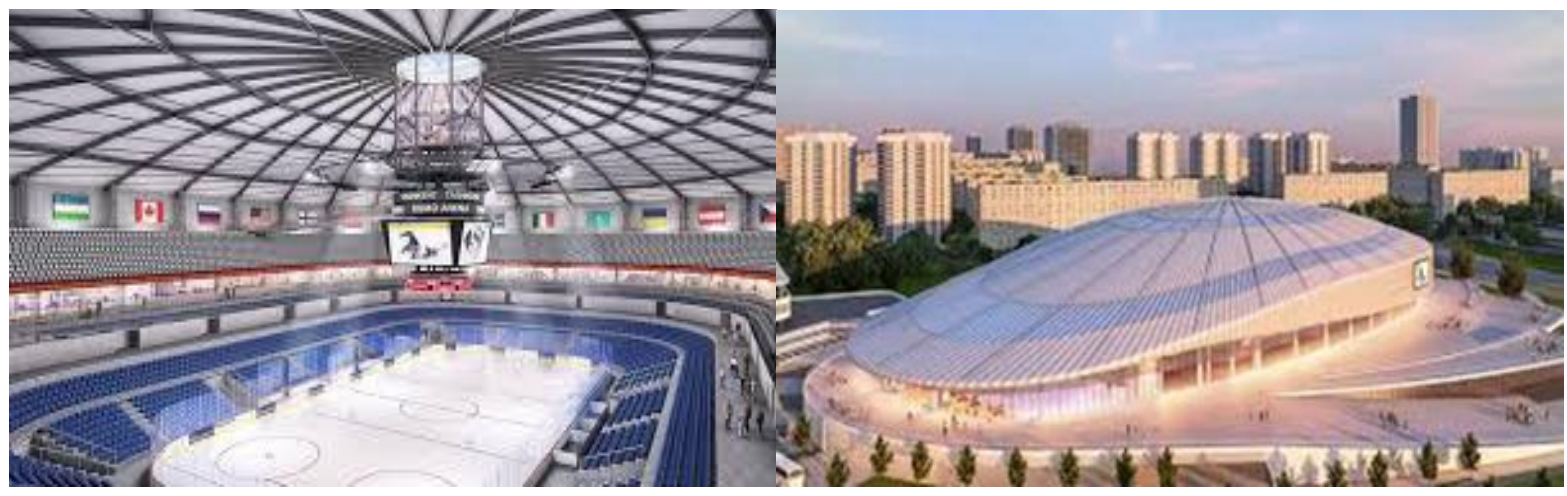

Figure 1. "Humo Arena" Ice Complex

The architectural idea of the Humo Arena is an image of the legendary Humo bird, which is widely distributed in Uzbekistan, symbolizing love, happiness and freedom, the arena itself and pedestrian walks in the form of bird wings. Greenfields, coastal and thematic architectural fields are carried out in accordance with the architectural idea of the complex.

Humo Arena is part of a large multifunctional sports complex. The main Ice Arena can accommodate 12500 people and is mainly used for ice hockey matches (there is also an opportunity to play hockey games). The main Ice Arena has facilities for disabled people, three VIP boxes for honorary guests, as well as 34 VIP boxes from 14 to 22 seats. The Hall has the ability to change the layout and the number of seats depending on the sporting event being held [1-3].
A small training Ice Arena can accommodate up to 200 people. Also, the Humo Arena has several dressing rooms for athletes, three sports and gyms, a fitness centre, a sports museum, a restaurant, a cafe and a sports bar overlooking the arena, a press centre, a press conference hall, additional equipment. auxiliary rooms and buildings, shops of sports equipment, educational and entertaining children's Zone, other sports and entertainment facilities. In the area next to Majmua, there are four levels of parking for motorways, recreation areas. The dimensions of the flying saucer in the skates of the main and small arenas correspond to the Olympic standard $(60 \times 30 \mathrm{~m})$.

Also in the Humo Arena, There are two ski simulators that are as close as possible to the real conditions for snowboarders and skiers. $30 \times 60 \mathrm{~m}$ (transformation $28 \times 60$ and 26×60). 
The project was developed by the American company Cushman \& Wakefield. 8 projects of the future business centre were selected as a concert proposed by the Turkish company Tabanlıoğlu Architects Architecture. Cushman \& Wakefield Inc. ( $C \& W$ ) is an American company specializing in trading operations with real estate. The headquarters of the company is located in Chicago, its headquarters is located in New York (America), London (EMEA), Sydney (APAC) and Bangalore (Asia). 72 per cent of C\&W belongs to the Rockefeller Group. In 2006, the holding company of the Agnelli family acquired 70 per cent of the share of IFIL (now EXOR) C\&W, which became its shareholder. Cushman \& Wakefield is one of the largest commercial real estate companies in the world and its revenue is about 6 billion dollars. The firm employs over 70 people in 400 offices in more than 48000 countries. Bret White (Chairman), Djon Forrester (President), Duncan Palmer.

In New York, John Clydesdale Kushman, the son of a major realtor in New York, and his father-in-law, Bernard Wakefield, formed their own company called Cushman \& Wakefield. The new organization was one of the first to offer property management services to commercial real estate owners. By 1922, C\&W had managed several buildings in Midtown Manhattan. He survived the Great Depression of the 1930s, and construction in the 1940s flourished, creating new opportunities for the company, in particular, he was involved in preparing the ground for the construction of the UN complex. In the 1960s, Cushman \& Wakefield began a national expansion and created a network of offices in the United States. In 1969, the RCA media conglomerate acquired Cushman \& Wakefield and in 1976 sold its stake to the Rockefeller Group. In 1989, Mitsubishi Estate became a shareholder in the Rockefeller Group. In 1990, C\&W entered the European market and bought the British company Healey \& Baker, founded in
1820 in London by George Healy, who leased the crown lands east and north of Regent Park during the construction of Regent Street. In 1910, George Henry joined Baker Healy as a partner. In 1920, when the firm was already renamed Healey \& Baker, it began dealing with commercial real estate. In 1994, a global C\&W partnership was established with several commercial real estate firms in the United States, Europe, Asia, South America, Mexico, and Canada. In 2001, C\&W acquired the Cushman Realty Corporation (CRC), founded in 1978 in Los Angeles, California, and thus expanded its presence on the West Coast and Southwest of the United States, resulting in CRC founder John. C. Cashman III and Louis B. Cashman returned to the firm founded by their grandfather, John Clydesdale Cashman, and his uncle, Bernard Wakefield. John S. Kashman served as chairman of Louis B. Kashman's board of directors and his deputy.

In 2002, the Cushman \& Wakefield Alliance program was launched. The company needed to expand customer service opportunities in U.S. markets without offices. In 2006, the Agnelli family holding company IFIL (now EXOR) acquired a 70\% stake in C\&W and became its shareholder.

In the 2000s, Cushman \& Wakefield made several acquisitions, including Sonnenblick Goldman (New York), Alston Knox (England), Stiles \& Riabokobylko (Russia), Royal LePage Commercial (Canada), and Brazil's Semco in 1994 by both companies. bought a stake in the formed joint venture and became its shareholder

In 2015, DTZ, a European real estate service provider, acquired Cushman \& Wakefield Inc. with the support of American investment company TPG Capital to create one of the largest real estate companies in the world. Cushman \& Wakefield and DTZ merged on September 1, 2015, for $\$ 2$ billion. At the time of the merger, both companies had $\$ 5$ billion in revenue, 43,000 employees, and managed 
about 400 million square feet of commercial real estate, bringing their owners more than \$ 191 billion in annual rental revenue. After the merger, the new company became a leader in twenty U.S. markets. In the spring of 2005, Cushman \& Wakefield Park Avenue sold the MetLife Building for $\$ 1.72$ billion. No building in New York's history had been purchased for that price. In 2007, Cushman \& Wakefield was appointed as the exclusive leasing agent for the only world shopping centre under construction.

The skyscraper will open in Manhattan in late 2013 and will include buildings with a total area of more than 280,000 square feet. In 2011, Cushman \& Wakefield signed Condé Nast to lease an office with a total area of more than 90,000 m2. That same year, Cushman \& Wakefield participated in a deal in which Google bought two buildings in Dublin for 100 million euros. This is the largest sale in the city since 2007.

Also in 2011, with the help of Cushman \& Wakefield in Singapore, the Capital Square office building, which covers an area of 35,860 $\mathrm{m} 2$, was sold for $\$ 715$ million. The company then introduced Nomura Holdings, which leased more than 80,000 square feet of space in Manhattan's Worldwide Plaza. Finally, the biggest deal in 2011 was to rent offices in Houston with a total area of more than 100,000 square feet. In 2012, Cushman \& Wakefield sold a 140,000-square-foot, 50-story One Court Square building in New York City. The client was a group of private investors. The combined company now operates under the Cushman \& Wakefield brand, with about $90 \%$ of the shares owned by a group of investors, including American investment company TPG Capital, PAG Asia Capital, one of Asia's largest alternative investment funds, and Canada's OTPP pension fund. arm. In June 2018, Cushman \& Wakefield submitted Form S1 to the U.S. Securities and Exchange Commission and announced its inclusion on the NYSE list.

\section{Hilton Hotel.}

- Investor: OOO «Akfa Dream World»

- Designer: ARUP(UK)

- General contractor: OOO "Discover Invest"

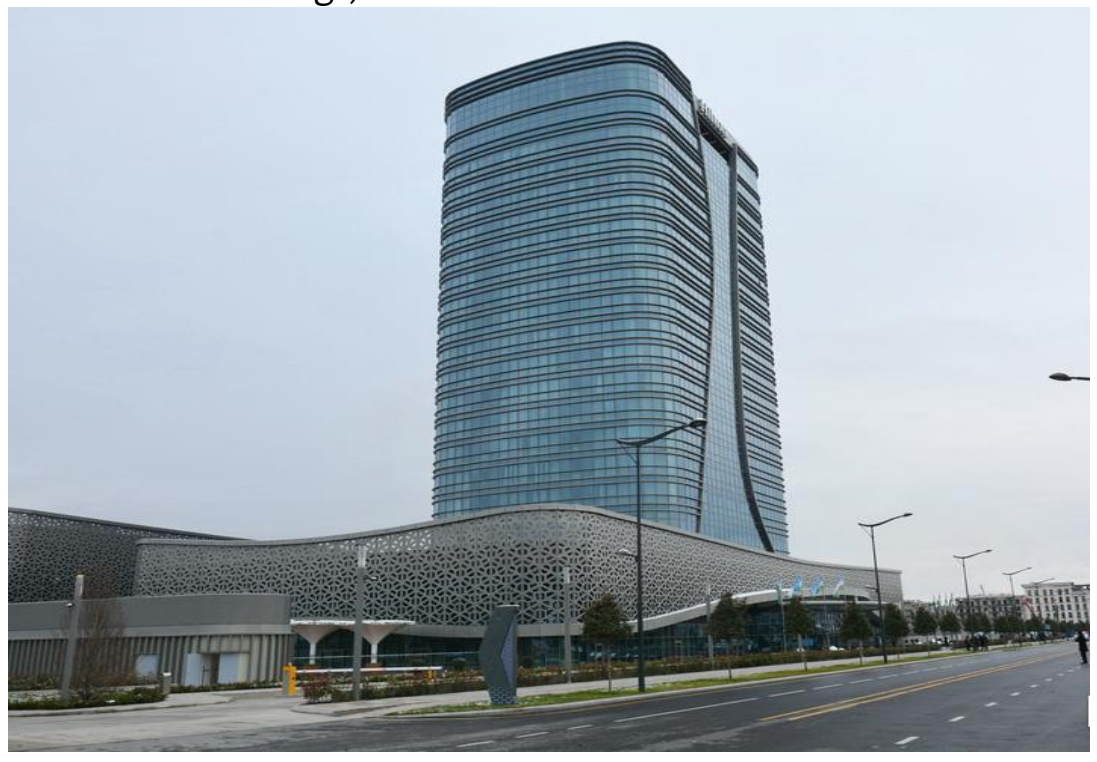

Figure 2. Hilton Tashkent Hotel 
The Congress Hall building and the Hilton Hotel are connected by a bridge. The interior and layout of the halls in the construction of the Congress Hall were designed by experts from Metex Design Group (Turkey). Construction was completed in October 2019. Hilton is a five-star, 21-story hotel with a height of 95.4 meters. It includes 258 rooms (8 of which are presidential rooms) [4].

Tashkent city. The main general project author is an American company called Cushman \& Wakefield. The company is managed in partnership by Brett White (chairman), John Forrester president, Duncan Palmers. The total area of Tashkent city is 80 hectares, the territory of Shayhantahur district, south-west of the intersection of Abay and Alisher Navoi streets in the centre of Tashkent.
The main general designer is the British company ARUP (Alan Belfield), the building project was developed in collaboration with the Turkish design bureau Metex Design Group. The bureau was established in Istanbul by architects Murat Tabanlıoğlu and Hayati Tabanlıoğlu. Murat Tabanioglu, Melkan Gursel Tabanlioglu have been partners since 1995 and Ozdem Gursel has been partners since 1997. The Bureau's work includes the Istanbul Modern Museum of Modern Art (Istanbul Modern) (2004).

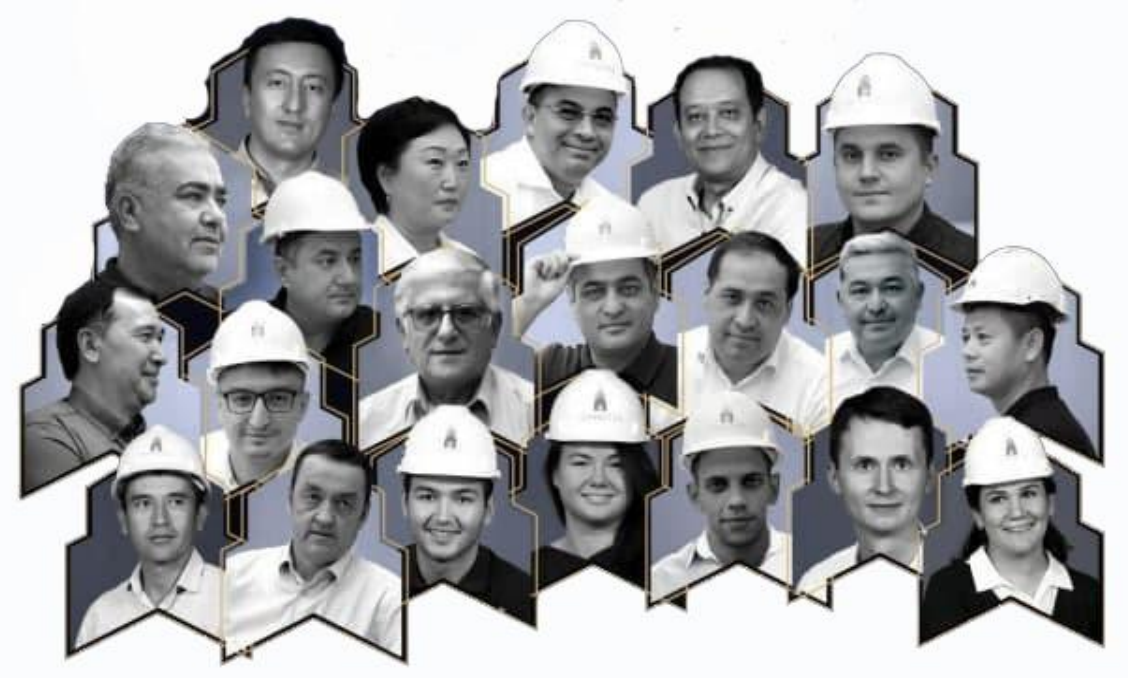

Figure 3. Foreign and local specialists working in the construction of Tashkent City

The project aims to show that Tashkent City is not just a huge, lifeless building, but an even more important process of discovery. It also means the kindness of the people who are working tirelessly to bring the country to a new, international position. More than a thousand foreign and local specialists are involved in the construction of Tashkent City. For this photo project, we selected 21 heroes
(Fig. 3)[4-7] . Each has its own story. Their destinies are unique and unique - some find time for their hobbies despite employment, others are able to save lives, and others are involved in the implementation of this idea.

\section{CONCLUSION}

In short, as a result of radical reforms in our country, our architects are building buildings 
that meet international standards and do not overlap in appearance. This shows that our country is developing and growing, but also requires more research from architects, the exchange of experience from leading international architects.

\section{REFERENCES}

1. nuz.uz. (2020, December 24). News of Uzbekistan today: nuz.uz electronic newspaper. News of Uzbekistan Today: Nuz.Uz. https://nuz.uz

2. O'zbekiston Milliy Kutubxonasi. (n.d.). @copy; O‘zbekiston Respublikasi Prezidenti Administratsiyasi Huzuridagi Axborot va Ommaviy Kommunikatsiyalar Agentligining Alisher Navoiy Nomidagi O'zbekiston Milliy Kutubxonasi. Retrieved December 25, 2020, from https://www.natlib.uz/

3. Bodio, T. (2020). Uzbekistan: A State Undergoing Total Reconstruction.

4. Hotel in Tashkent - Hilton Tashkent City - Uzbekistan. (2020). Hilton.Com. https://www.hilton.com/en/hotels/tast chi-hilton-tashkent-

city/?WT.mc_id=zCBECoUZ1HI2Natural Search3Google_LGHotelListing4DGGe neric_5LocalSearch6TASTCHI7EN8ig23 30

5. Xabibova, S. I., \& Usmanov, F. S. (2020). Level of Tourism Development in Uzbekistan at the Recent Stage. Indonesian Journal of Law and Economics Review, 8, 10-21070.

6. Kosimova, S. H., \& Kosimov, L. M. (2020). Principles of forming a gardenpark landscape design around historical monuments of the fergana valley. ACADEMICIA: An International Multidisciplinary Research Journal, 10(6), 1582-1589.

7. Qosimov, L. M., Qosimova, S. F., \& Tursunov, Q. Q. (2020). Specific aspects of using ferghana region's pilgrims for touristic purposes. Academic research in educational sciences, (3). 